\title{
Penanganan Penyimpanan Kentang Bibit (Solanum tuberosum L.) di Bandung
}

Storage Handling of Potato Tuber as Seed (Solanum tuberosum L.) in Bandung

\author{
Afifah Farida Jufri, Megayani Sri Rahayu*, Asep Setiawan
}

Departemen Agronomi dan Hortikultura, Fakultas Pertanian, Institut Pertanian Bogor (Bogor Agricultural University), Jl. Meranti, Kampus IPB Darmaga, Bogor 16680, Indonesia Telp. \& Faks.62-251-8629353 e-mail agronipb@indo.net.id

*Penulis untuk korespondensi: megasetiawan23@yahoo.com

Disetujui 7 Januari 2015/ Publish online 15 januari 2015

\begin{abstract}
The purpose of the research was getting experience and learning something new about technical aspect in planting potato, post harvest handling of potato tuber as consumption and as seed in technical. Reasearch started from February until June 2011 in Margamukti, Pangalengan, Bandung, West Java. The observation result of temperature storage and tuber diameter for dormancy of tuber showed that tuber in cold storage not sprouting after 16 weeks, while tuber in room temperature storage sprouting in 12 weeks and $100 \%$ sprouting in $16^{\text {th }}$ week. Reduction of tuber weight in room temperature is greater than in cold storage. Pest and disease found more in room temperature storage, that is $16.47 \%$. The result of tuber storage treatment of sprout growth showed that tuber which stored with storage method II (two months stored in room temperature storage continued with $\mathrm{CS}_{2}$ gas treatment) meet the slower sprout growth than storage method I (four months stored in room storage) and storage method III ( two months storage in room storage and three months in cold storage).
\end{abstract}

Keywords : potato, post harvest, cold storage, tuber seed

\section{ABSTRAK}

Tujuan penelitian adalah untuk memperoleh pengalaman dan mempelajari kegiatan budidaya tanaman kentang, penanganan pasca panen kentang konsumsi dan kentang bibit serta pemasarannya baik secara teknis. Penelitian dilaksanakan mulai Februari-Juni 2011 di Desa Margamukti, Kecamatan Pangalengan, Kabupaten Bandung, Provinsi Jawa Barat. Hasil pengamatan terhadap pengaruh suhu simpan dan diameter umbi terhadap masa dormansi menunjukkan umbi yang disimpan di suhu dingin $\left(4^{0} C\right)$ belum mengalami pertunasan setelah 16 minggu penyimpanan sedangkan umbi yang disimpan di suhu ruang mulai bertunas pada minggu ke-12 dan mencapai 100\% pada minggu ke 16. Penurunan bobot umbi yang disimpan di suhu ruang lebih besar daripada umbi yang disimpan di suhu dingin. Hama penyakit lebih banyak ditemui pada umbi yang disimpan di suhu ruang yaitu sebesar 16.47\%. Hasil pengamatan pengaruh perlakuan penyimpanan umbi terhadap pertumbuhan tunas menunjukkan bahwa umbi yang disimpan menggunakan metode II (penyimpanan umbi selama 2 bulan di suhu ruang dilanjutkan pemberian gas CS $_{2}$ ) mengalami pertumbuhan tunas yang lebih lambat daripada metode simpan I (penyimpanan umbi selama 4 bulan di suhu ruang) dan metode simpan III (penyimpanan umbi selama 2 bulan di suhu ruang dan 3 bulan di suhu dingin).

Kata kunci : kentang, pasca panen, penyimpanan dingin, benih umbi 


\section{PENDAHULUAN}

Indonesia merupakan negara agraris yang sebagian masyarakatnya bekerja pada bidang pertanian, salah satunya tanaman hortikultura. Tanaman hortikultura memberikan kontribusi yang cukup besar dalam kebutuhan pangan, peningkatan ekspor, peningkatan pendapatan petani dan pemenuhan gizi keluarga. Salah satu tanaman hortikultura yang memiliki peluang untuk memenuhi kebutuhan pangan adalah tanaman kentang (Solanum tuberosum L). Tanaman kentang memiliki potensi dan prospek yang baik untuk mendukung program diversifikasi dalam rangka mewujudkan ketahanan pangan berkelanjutan (The International Potato Center, 2008).

Tanaman kentang merupakan salah satu bahan makanan yang mengandung jenis karbohidrat kompleks. Kandungan karbohidrat pada kentang mencapai sekitar 18\%, protein $2.4 \%$ dan lemak $0.1 \%$. Total energi yang diperoleh dari 100 gram kentang adalah sekitar 80 kkal (Astawan, 2004), sehingga kentang dapat digunakan sebagai pengganti nasi. Kentang juga mengandung vitamin $\mathrm{C}$ yang mencapai $31 \mathrm{mg}$ dalam 100 gram kentang. Kentang dapat dimanfaatkan sebagai campuran dalam olahan kue, perkedel, kroket, bubur, kripik kentang (potato chip), kentang goreng, kukus, rebus, dan salad.

Produktivitas kentang di Indonesia pada tahun 2009 sebesar 16.51 ton/ha dan pada tahun 2010 menurun menjadi 15.95 ton/ha (BPS, 2011). Produktivitas kentang di Indonesia masih berada dibawah produktivitas kentang di Eropa yang mencapai 25.0 ton/ha (The International Potato Center, 2008). Rendahnya produktivitas tersebut disebabkan oleh teknik budidaya yang belum optimal, penanganan pasca panen yang kurang baik dan kurangnya ketersediaan bibit yang bermutu dan bersertifikat. Data Direktorat Jendral Hortikultura (2010) menunjukkan bahwa pada tahun 2008 kebutuhan bibit kentang sebesar 96 277 ton sedangkan ketersediaan bibit bersertifikat dalam negeri hanya sebesar 8066 ton $(8.3 \%)$. Hidayat (2010) menyatakan pemenuhan kebutuhan bibit kentang bersertifikat secara nasional hingga kini hanya mencapai $10 \%$, sedangkan sisanya menggunakan bibit hasil seleksi sendiri yang berkualitas rendah.

Salah satu faktor yang mempengaruhi ketersediaan bibit dan rendahnya mutu kentang bibit adalah cara penyimpanan di gudang (Pantastico, 1975). Penyimpanan kentang bibit bertujuan untuk mencegah dan mengurangi kerugian akibat kerusakan panen yang dapat menjadi sumber berkembangnya penyakit pada bibit.

Kentang bibit memiliki masa dormansi dimana umbi kentang tidak akan bertunas sampai waktu tertentu. Selama masa dormansi, kentang bibit dapat disimpan di gudang bersuhu dingin (cool storage) dan di gudang terang bersuhu ruang. Penyimpanan kentang bibit pada gudang bersuhu dingin dapat memperpanjang masa dormansi sedangkan penyimpanan di suhu ruang akan menyebabkan umbi bertunas sesuai masa dormansinya. Masa dormansi kentang bibit dapat dipercepat dengan pemberian gas $\mathrm{CS}_{2}$ atau penyimpanan kentang bibit pada suhu berganti.

Penyimpanan kentang bibit di suhu dingin dilakukan jika produksi kentang bibit melebihi permintaan pasar sehingga pertunasan kentang bibit dapat ditunda karena masa dormansi menjadi lebih panjang. Penyimpanan kentang bibit di suhu ruang dilakukan jika produksi bibit sama dengan permintaan pasar sehingga pertunasan kentang sesuai dengan waktu tanam. Pematahan dormansi tersebut dilakukan jika produksi bibit lebih sedikit daripada permintaan bibit saat musim tanam. Pengaturan penyimpanan kentang bibit tersebut dapat menjaga ketersediaan kentang bibit. Penelitian ini bertujuan untuk mengetahui pengaruh suhu simpan dan diameter umbi terhadap masa dormansi dan pengaruh perlakuan penyimpanan terhadap pertumbuhan tunas bibit kentang di Pangalengan, Bandung, Jawa Barat.

\section{BAHAN DAN METODE}

Kegiatan dilaksanakan pada Februari sampai Juni 2011. Pelaksanaan penelitian bertempat di Desa Margamukti, Kecamatan Pangalengan, Kabupaten Bandung, Jawa Barat. Kegiatan tersebut dilakukan sesuai dengan kondisi di lapangan dengan mengikuti standar operasional di lapangan yaitu budidaya kentang dengan aspek khusus penyimpanan.

\section{HASIL DAN PEMBAHASAN}

\section{Produksi Kentang Bibit}

Produksi kentang bibit di lahan penelitian mencapai 1000 ton/tahun, mulai bibit jenis G1 sampai G4. Varietas yang diproduksi adalah $75 \%$ varietas Granola, 20\% Nadia dan 5\% varietas lain. Proses produksi mulai dari penanaman di lapang hingga penyimpanan di gudang mendapat pengawasan dari Balai Pengawasan dan Sertifikasi Benih Tanaman Pangan dan Hortikultura (BPSBTPH). 
Bibit G0 diperoleh melalui aklimatisasi planlet kentang di green house. Bibit G1 diperoleh dari penanaman bibit G0 di screen house, sedangkan bibit G2, G3 dan G4 diperoleh dari penanaman bibit generasi sebelumnya dan ditanam di lapangan. Produksi bibit G0 dan G1 memerlukan pemeliharaan yang lebih intensif karena bibit tersebut merupakan induk untuk pembibitan selanjutnya (Tabel 1). Kesehatan tanaman dan umbi hasil untuk pembibitan sangat diperhatikan agar bibit dapat digunakan sampai generasi ke-4. Bibit yang tidak sehat akan menurunkan produksi dari generasi selanjutnya. Secara teoritis produksi bibit dari generasi ke generasi akan mengalami penurunan. Penurunan terjadi karena daya tahan bibit terhadap penyakit untuk generasi selanjutnya semakin rendah sehingga tanaman mudah terserang hama dan penyakit (Gildemacher et al., 2007).

Tabel 1. Produksi dan produktivitas kentang bibit varietas Granola

\begin{tabular}{cccccc}
\hline Luas lahan (ha) & Generasi & Total produksi $(\mathrm{kg})$ & Bibit afkir & Produktivitas $\left(\mathrm{kg} \mathrm{ha}^{-1}\right)$ & Persentase afkir $(\%)$ \\
\hline 0.78 & G2 & 16823.19 & 303.19 & 21568.19 & 1.80 \\
0.80 & G3 & 12997.96 & 310.96 & 16247.45 & 2.39 \\
2.00 & G4 & 39562.40 & 777.4 & 19781.20 & 1.96 \\
\hline
\end{tabular}

Kentang bibit G2 dihasilkan dari kentang G1. Kentang bibit G3 dihasilkan dari penanaman G2 dan kentang bibit G4 dihasilkan dari penanaman G3. Tabel 1 menunjukkan bahwa G2 memiliki produktivitas yang paling tinggi yaitu sebesar 21568.19 kg/ha. G3 memiliki produktivitas terendah yaitu $16247.45 \mathrm{~kg} / \mathrm{ha}$. Rendahnya produksi bibit G3 dibandingkan G4 antara lain disebabkan oleh penggunaan bibit G2 yang terinfeksi penyakit, cara penanaman yang kurang baik dan keadaan lingkungan saat tanam yang kurang menuntungkan. Persentase bibit afkir pada G3 lebih tinggi dari bibit lainnya. Hal ini menunjukkan bahwa bibit yang digunakan ketika menanam memiliki kualitas yang rendah. Selain itu ketika panen G3 banyak umbi yang dibuang karena busuk dan tidak layak untuk panen.

\section{Persentase Umbi Terserang Hama dan Penyakit}

Penyortiran dilakukan terhadap umbi yang akan dijadikan bibit untuk mencegah penyebaran hama dan penyakit. Sortasi bibit merupakan kegiatan penting yang harus dilakukan sebelum dan selama bibit disimpan di gudang baik di suhu dingin atau di suhu ruang dengan memisahkan umbi yang sehat dan umbi yang mengalami kerusakan akibat kerusakan mekanik dan serangan hama dan penyakit. Penyortiran untuk kentang bibit dilakukan mulai dari lapangan hingga ke gudang.

Kerusakan umbi selama penyimpanan dipengaruhi oleh beberapa faktor yaitu tumpukan umbi selama penyimpanan, suhu penyimpanan dan sirkulasi udara. Umbi yang disimpan dengan tumpukan yang lebih tinggi menyebabkan sirkulasi udara kurang baik sehingga gudang menjadi lebih lembab. Udara yang lembab akan mendukung perkembangan hama dan penyakit. Secara teoritis gudang dengan suhu kamar $\left(18^{0}\right.$ - $\left.25^{\circ} \mathrm{C}\right)$ memberikan kondisi yang baik bagi perkembangan hama dan penyakit gudang. Gudang dengan suhu dingin $\left(4^{0} \mathrm{C}\right)$ dapat menekan perkembangan patogen. Persentase jumlah umbi yang terserang hama dan penyakit dapat dilihat pada Tabel 2.

Tabel 2 menunjukkan bahwa persentase kerusakan umbi selama penyimpanan di suhu kamar lebih tinggi (16.47\%) daripada penyimpanan umbi di suhu dingin (12.57\%). Pada minggu ke-16 setelah penyimpanan, jumlah umbi yang mengalami kerusakan akibat hama dan penyakit berkurang, hal ini karena selama 3 bulan pertama dilakukan sortasi terhadap umbi yang mengalami kerusakan oleh hama dan penyakit. Berdasarkan pengamatan kerusakan umbi terutama disebabkan oleh hama penggerek umbi kentang (Phthorimaea operculella Zell.), penyakit busuk kering (Fusarium spp.), penyakit busuk lunak (Erwinia carotovora) dan penyakit busuk mata (Ralstonia solanacearum).

Serangan hama Phthorimaea operculella Zell berasal dari lapangan. Telur yang menempel di mata umbi akan menetas dan akan memakan mata tunas umbi. Hama penggerek umbi kentang ini lebih sering ditemui pada musim kemarau.

Perkembangan bakteri Erwinia carotovara akan lebih cepat bila kondisi ruangan lebih panas. Hasil pengujian menunjukkan bahwa bibit yang diinkubasikan pada temperature antara $25^{\circ}-30^{\circ} \mathrm{C}$ mampu mempercepat perkembangan infeksi bakteri Erwinia spp (Perombelon, 1976). Kerusakan bibit yang paling banyak ditemui disebabkan oleh Ralstonia ssolanacearum. Menurut Sequeira dan Graham (1977) bahwa penyakit bakteri yang paling berbahaya adalah $R$. solanacearum yang menyerang pada fase awal dan tidak dapat dideteksi dengan mata telanjang.

Kentang yang telah disortasi akan diperiksa kembali oleh BPSBTPH untuk 
mendapatkan sertifikat dan disimpan di suhu dingin dan suhu ruang. Kentang akan disimpan di suhu dingin apabila permintaan terhadap bibit rendah tetapi produksi bibit tinggi. Hal ini untuk memperpanjang masa dormansi agar tunas muncul tepat waktu, yaitu pada saat akan tanam. Penyimpanan umbi kentang di suhu ruang dilakukan ketika produksi bibit rendah dan permintaan bibit tinggi.

Tabel 2. Persentase umbi yang terserang hama dan penyakit selama 4 bulan di suhu kamar dan suhu dingin.

\begin{tabular}{|c|c|c|c|c|c|c|c|}
\hline \multirow{2}{*}{ Suhu simpan } & \multirow{2}{*}{$\begin{array}{c}\text { Jumlah } \\
\text { umbi awal }\end{array}$} & \multicolumn{4}{|c|}{ Jumlah umbi yang rusak } & \multirow{2}{*}{ Total } & \multirow{2}{*}{$\begin{array}{c}\text { Persentase } \\
(\%)\end{array}$} \\
\hline & & $4 \mathrm{MSS}$ & $8 \mathrm{MSS}$ & $12 \mathrm{MSS}$ & $16 \mathrm{MSS}$ & & \\
\hline Suhu kamar & 170 & 10 & 10 & 5 & 3 & 28 & 16.47 \\
\hline Suhu dingin & 167 & 5 & 3 & 8 & 5 & 21 & 12.57 \\
\hline
\end{tabular}

Keterangan : MSS = Minggu setelah simpan

\section{Pengaruh Suhu Simpan dan Diameter Umbi terhadap Masa Dormansi Umbi}

Umbi bibit kentang dapat disimpan di gudang bersuhu ruang dan suhu dingin. Penyimpanan kentang di suhu dingin $\left(4^{0} \mathrm{C}\right)$ dapat memperpanjang masa dormansi kentang sedangkan umbi yang disimpan di gudang bersuhu ruang akan lebih cepat bertunas (Tabel 3). Varietas yang diamati adalah varietas granola generasi ke-3 (G3). Menurut Beukema dan Zaag (2007), penyimpanan umbi kentang pada suhu dingin dapat menunda pertunasan sampai 12 bulan sedangkan penyimpanan pada suhu $18^{0}-25^{\circ} \mathrm{C}$ umbi akan bertunas setelah 3-4 bulan.

Pengamatan secara visual menunjukkan bahwa umbi yang disimpan pada suhu kamar mulai bertunas pada minggu ke 12 sedangkan umbi yang disimpan pada suhu dingin belum bertunas hingga minggu ke 16. Umbi yang disimpan di suhu kamar lebih cepat bertunas karena proses respirasi yang tinggi sehingga terjadi perombakan cadangan makanan. Perombakan cadangan makanan tersebut akan mendorong pertumbuhan tunas. Suhu yang lebih dingin menyebabkan kegiatan respirasi yang terjadi pada umbi lebih rendah sehingga pertumbuhan tunas akan membutuhkan waktu yang lebih lama (Goldsworthy dan Fisher, 1992).

Selama penyimpanan, bobot umbi akan mengalami penurunan. Umbi kentang terdiri dari $80 \%$ air. Kehilangan bobot dapat disebabkan oleh kehilangan air. Air dalam umbi lebih mudah hilang di suhu ruang daripada di suhu dingin melalui proses evaporasi. Evaporasi umbi kentang akan lebih besar terjadi pada suhu kamar daripada suhu dingin (Beukema dan Zaag, 2007). Penurunan bobot setelah tumbuh tunas menjadi lebih besar karena proses respirasi dan evapotranspirasi akan menjadi lebih tinggi. Perbedaan penurunan bobot akibat suhu penyimpanan yang berbeda dapat dilihat pada Tabel 3.
Tabel 3. Penurunan bobot umbi varietas Granola G3 berdasarkan suhu penyimpanan

\begin{tabular}{|c|c|c|c|c|}
\hline \multirow{2}{*}{ Perlakuan } & \multicolumn{4}{|c|}{ Umur } \\
\hline & $4 \mathrm{MSP}$ & $8 \mathrm{MSP}$ & $12 \mathrm{MSP}$ & $16 \mathrm{MSP}$ \\
\hline Subu & \multicolumn{4}{|c|}{ 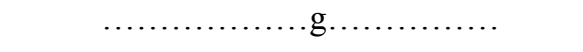 } \\
\hline dingin & $1.95^{\mathrm{a}}$ & $2.35^{\mathrm{a}}$ & $16^{\mathrm{a}}$ & $23^{a}$ \\
\hline Suhu & & & & \\
\hline kamar & $3.5^{\mathrm{b}}$ & $2.95^{\mathrm{b}}$ & $3.05^{\mathrm{b}}$ & $4.45^{\mathrm{b}}$ \\
\hline Keterangan & \multicolumn{4}{|c|}{$\begin{array}{l}\text { Nilai pada kolom yang sama yang diikuti oleh } \\
\text { huruf yang berbeda menunjukkan berbeda } \\
\text { nyata berdasarkan uji DMRT pada taraf 5\% } \\
\text { MSP = Minggu Setelah Perlakuan }\end{array}$} \\
\hline
\end{tabular}

Penurunan bobot umbi yang disimpan di suhu dingin tidak mengalami penurunan yang signifikan dari 4-16 MSP. Penurunan bobot tidak berbeda nyata jika dilihat dari ukuran umbi. Data dapat dilihat pada Tabel 4. Hal ini diduga karena perbedaan ukuran umbi yang tidak terlalu berbeda yaitu diameter > $55 \mathrm{~mm}$ untuk ukuran L (besar) dan 45-55 mm untuk ukuran M (sedang). Jumlah umbi dengan ukuran diameter > $55 \mathrm{~mm}$ yang bertunas telah mencapai $100 \%$ pada minggu ke-16 sedangkan umbi dengan diameter $45-55 \mathrm{~mm}$ baru mencapai $90 \%$.

Tabel 4. Penurunan bobot umbi varietas Granola G3 ukuran umbi (diameter)

\begin{tabular}{ccccc}
\hline Ukuran & \multicolumn{4}{c}{ Umur } \\
\cline { 2 - 5 } umbi & 4 MSP & 8 MSP & 12 MSP & 16 MSP \\
\hline & \multicolumn{3}{c}{$\ldots \ldots \ldots \ldots \ldots . \ldots \ldots \ldots \ldots$} \\
$>55$ & $2.90^{\mathrm{a}}$ & $2.8^{\mathrm{a}}$ & $2.55^{\mathrm{a}}$ & $3.30^{\mathrm{a}}$ \\
$45-55$ & $2.55^{\mathrm{a}}$ & $2.5^{\mathrm{a}}$ & $2.10^{\mathrm{a}}$ & $3.45^{\mathrm{a}}$ \\
\hline
\end{tabular}

Keterangan : Nilai pada kolom yang sama yang diikuti oleh huruf yang berbeda menunjukkan berbeda nyata berdasarkan uji DMRT pada taraf 5\% MSP = Minggu Setelah Perlakuan

Pengaruh Metode Penyimpanan Umbi Kentang terhadap Pertumbuhan Tunas

Umbi kentang akan mulai bertunas setelah masa dormansi berakhir. Lama masa dormansi kentang dipengaruhi oleh varietas kentang, umur umbi saat panen, keadaan lingkungan saat tanam 
dan kondisi simpan umbi (Beukema dan Zaag, 2007). Masa dormansi dapat dipercepat dengan menyimpan umbi pada suhu yang lebih tinggi $\left(18^{0}-25^{\circ} \mathrm{C}\right)$, menyimpan umbi dengan suhu yang berganti dan menggunakan perlakuan kimia. Penyimpanan umbi dengan suhu berganti yaitu umbi disimpan di suhu dingin dengan waktu tertentu kemudian menyimpan umbi tersebut pada suhu yang tinggi. Pematahan dormansi dengan perlakuan kimia dapat menggunakan giberelin $\left(\mathrm{GA}_{3}\right)$ atau gas karbon disulfide $\left(\mathrm{CS}_{2}\right)$.

Pematahan dormansi menggunakan suhu dan perlakuan kimia mempengaruhi jumlah tunas dan pertumbuhan tunas. Jumlah tunas yang muncul akan mempengaruhi jumlah batang pada tanaman.

Penyimpanan umbi pada suhu ruang (Metode Simpan I) diharapkan mempercepat pertumbuhan tunas dan memiliki jumlah tunas yang banyak. Penyimpanan pada suhu berganti (Metode Simpan III) diharapkan dapat menekan pertumbuhan tunas ketika penyimpanan di suhu dingin dan kecepatan tumbuh tunas akan menjadi lebih cepat ketika umbi dipindah ke suhu tinggi. Kecepatan pertumbuhan tunas tersebut diduga karena umbi yang mengalami stress lingkungan simpan akan mempengaruhi kegiatan respirasi dan mendorong pertumbuhan tunas. Penyimpanan menggunakan $\mathrm{CS}_{2}$ (Metode Simpan II) diharapkan dapat mengurangi jumlah tunas yang muncul akibat adanya fenomena dominasi apikal.

Pengamatan secara visual menunjukkan bahwa umbi yang disimpan dengan metode simpan I (suhu kamar) mulai bertunas setelah 1 MSP dan mencapai $100 \%$ setelah 3 MSP, umbi yang disimpan dengan metode simpan III (suhu berganti) mulai bertunas pada 2 MSP dan mencapai $100 \%$ pada 3 MSP, dan umbi yang diberi gas $\mathrm{CS}_{2}$ (penyimpanan II) mulai bertunas pada 3 MSP dan mencapai $100 \%$ pada 7 MSP yang dapat dilihat pada Tabel 5 .

Tabel 5 dapat dilihat bahwa metode simpan II (gas) terlihat paling berhasil memperlambat munculnya tunas dibandingkan dua metode penyimpanan lainnya. Meskipun demikian dari percobaan ini belum dapat ditarik kesimpulan yang konklusif bahwa penyebab nya adalah akibat pemberian gas CS 2 semata. Hal ini disebabkan oleh berbedanya lama penyimpanan umbi dalam ketiga metode penyimpanan tersebut.

Tabel 5. Waktu muncul tunas pada umbi yang disimpan berdasarkan metode simpan

\begin{tabular}{|c|c|c|c|c|c|c|c|c|}
\hline \multirow{2}{*}{ Perlakuan } & \multicolumn{8}{|c|}{ Waktu muncul tunas (MSP) } \\
\hline & 1 & 2 & 3 & 4 & 5 & 6 & 7 & 8 \\
\hline & & & & & & & & \\
\hline Metode simpan I & 60 & 70 & 100 & & & & & \\
\hline Metode simpan II & 0 & 0 & 10 & 60 & 70 & 90 & 100 & \\
\hline Metode simpan III & 0 & 20 & 100 & & & & & \\
\hline
\end{tabular}

Jumlah tunas yang dihasilkan oleh umbi yang mendapat perlakuan metode simpan I (suhu ruang selama empat bulan) dan umbi yang mendapat perlakuan metode simpan III (disimpan dengan suhu berganti) memiliki jumlah tunas yang tidak berbeda nyata yaitu 8 dan 7 tunas. Umbi yang mendapatkan perlakuan Metode Simpan II (gas) memiliki jumlah tunas yang nyata lebih sedikit (6 tunas) daripada dua perlakuan lainnya yang dapat dilihat pada Tabel 6. Hasil ini diduga akibat Gas $\mathrm{CS}_{2}$ yang merangsang pertumbuhan tunas apikal sedangkan pertumbuhan tunas apikal akan menghambat pertumbuhan tunas samping.
Pada Tabel 6 juga dapat dilihat bahwa panjang tunas yang dihasilkan oleh metode simpan II nyata lebih pendek daripada metode simpan lainnya. Hal ini karena umbi yang disimpan dengan metode simpan II mulai bertunas pada minggu ketiga sehingga mempengaruhi pertumbuhan panjang tunas. Jumlah tunas dan panjang tunas tidak mempengaruhi penurunan bobot umbi. Pada tabel dapat dilihat penurunan bobot umbi terhadap ketiga metode simpan tidak berbeda nyata.

Tabel 6. Pengaruh Metode Simpan terhadap pertumbuhan tunas pada 8 MSP

\begin{tabular}{lccr}
\hline Perlakuan & \multicolumn{2}{c}{ Pertumbuhan Tunas } \\
\cline { 2 - 4 } & Jumlah tunas (tunas) & Panjang tunas (cm) & Penurunan bobot umbi (gram) \\
\hline Metode simpan I & $8^{\mathrm{b}}$ & $1.20^{\mathrm{b}}$ & $1.44^{\mathrm{b}}$ \\
Metode simpan II & $6^{\mathrm{a}}$ & $0.73^{\mathrm{a}}$ & $2.00^{\mathrm{ab}}$ \\
Metode simpan III & $7^{\mathrm{b}}$ & $1.17^{\mathrm{b}}$ & $2.66^{\mathrm{b}}$ \\
\hline Keterangan : & Nilai pada kolom yang sama yang diikuti oleh huruf yang berbeda menunjukkan berbeda nyata berdasarkan uji
\end{tabular}




\section{KESIMPULAN}

Produktivitas kentang umumnya lebih tinggi jika menggunakan bibit dari kelas yang lebih tinggi, akan tetapi mutu dari bibit yang digunakan juga sangat menentukan tingkat produktivitas. Persentase umbi terserang hama dan penyakit cenderung lebih sedikit ditemukan pada umbi yang disimpan pada suhu dingin $\left(4^{\circ} \mathrm{C}\right)$ dibandingkan umbi yang disimpan pada suhu kamar $\left(18^{\circ} \mathrm{C}-25^{\circ} \mathrm{C}\right)$. Masa dormansi umbi akan lebih lama jika umbi disimpan pada suhu $4^{0} \mathrm{C}$, sehingga dapat disimpan lebih lama pada suhu dingin daripada suhu kamar. Umbi kentang yang telah disimpan selama 2 bulan pada suhu kamar diikuti dengan pemberian gas CS2 selama 24 jam (Metode Simpan II) memiliki pertumbuhan tunas yang lebih lambat

\section{DAFTAR PUSTAKA}

Astawan. 2004. Kentang: Sumber Vitamin C dan Pencegah Hipertensi [Internet]. [diunduh 20 Sept 2010]. Tersedia pada http://www.gizi.net.

[BPS] Badan Pusat Statistik. 2011. luas panen, produksi, dan produktivitas kentang 20092010 [Internet]. [diunduh 5 Juli 2010]. Tersedia pada http://www.bps.go .id.

Beukema, H.P., Zaag, D.E. van der. 2007. Introduction to Potato Production. Edisi 3. Pudoc Wageningen. Netherland. $179 \mathrm{p}$.
Gildemacher, Demo, P., Kinyae, P., Nyongesa, M., Mundia, P. 2007. Memilih tanaman terbaik untuk benih kentang. Salam. 20:16-18.

Goldsworthy,,P.T., Fisher, N.M. 1992. Fisiologi Tanaman Budidaya Tropik (diterjemahkan dari : the Physiology of Tropical Field Crops, penerjemah : Tohari). Yoyakarta (ID): Fakultas Pertanian. UGM.

Pantastico. 1975. Kandungan zat pati dan menuanya daun merupakan petunjukpetunjuk pemanenan bagi kentang dalam teknik penyimpanan bibit kentang oleh Ir. Wawan Wintarasa. Dinas pertanian tanman pangan propinis DT. Jawa Barat. Balai Benih Induk kentang. Pangalengan japan Internasional Cooperation Agency. 1997

Perombelon, M.C.M. 1976. Effect of environmental factor during the growing season on the level of potato tuber contamination by Erwinia carotovora. Phytopath Z. 85:97-116.

Sequeira, L., Graham, T.L. 1977. Agglutination of avirulent strains of Pseudomonas solanacearum by potato lectin. Physiol. Plant. Pathol. 11:43-54.

The International Potato Center . 2008. Facts and Figures: 2008 - The International Year of the Potato. CIP [Internet]. [diunduh 5 Okt 2010]. Tersedia pada http://www.potato 2008.org . 